\title{
FORMULATION AND EVALUATION OF ORODISPERSIBLE TABLETS OF DONEPEZIL HYDROCHLORIDE USING MODIFIED POLYSACCHARIDES
}

\author{
*P.K. Lakshmi, R. Sreekanth, M.M. Husnien Ali \\ Department of Pharmaceutics, G. Pulla Reddy College of Pharmacy, Hyderabad, India
}

Received 04 Feb 2015; Review Completed 13 March 2015; Accepted 13 March 2015, Available online 15 March 2015

\begin{abstract}
The objective of the study was to prepare and evaluate orodispersible tablets of Donepezil Hydrochloride (DPH) using natural modified polysaccharides such as modified karaya gum and modified agar with glycine and mannitol. The prepared formulations were compared with Kyron T-314, a super disintegrant, spray dried lactose, a diluent for improvement in DT and other ODT parameters. FTIR studies revealed no interaction between DPH and excipients. Precompression parameters for all formulations were found to be satisfactory. The oral dispersible tablets formulated using modified agar with glycine showed better disintegration time compared to modified karaya gum formulations. Different concentrations of mannitol and glycine were used in the formulation to study the improvement in the DT. The glycine formulations with modified agar gave better ODT parameters than modified karaya gum with mannitol and glycine formulations. The optimized formulations of modified agar with glycine in different concentrations were prepared with spray dried lactose as diluent and compared with formulations of Kyron T-314 as superdisintegrant with spray dried lactose as diluent. The results of lactose and spray dried lactose as diluents in these formulations did not show any significant difference in ODT evaluation parameters. The formulations were optimized using ODT parameters such as disintegration time, wetting time, water absorption ratio and other physicochemical evaluation parameters. The accelerated stability studies of optimized formulation did not show significant changes compared to initial physicochemical evaluation parameters. To conclude, modified polysaccharides with glycine can be used as superdisintegrant, which may be a cost effective alternative in comparison to synthetic superdisintegrant like Kyron T-314.

Keywords: Orodispersible Tablets, Donepezil Hydrochloride, modified karaya gum and modified agar
\end{abstract}

\section{INTRODUCTION}

Tablet is the most widely used dosage form because of its convenience in terms of self-administration, compactness and ease in manufacturing. However, geriatric and paediatric patients experience difficulty in swallowing conventional tablets, which lead to poor patient compliance. To overcome these problems, scientists developed innovative drug delivery systems known as "Oral Disintegrating Tablets" (ODT). These are novel type of tablets that disintegrate/disperse/dissolve in saliva ${ }^{1,2,3}$. The target populations for these oral disintegrating dosage forms have generally been paediatric, geriatric and bedridden or developmentally disabled patients who have dysphagia. Patients with persistent nausea, sudden episodes of allergic attacks or coughing, who are travelling, or who have little or no access to water are also good candidates for oral disintegrable tablets ${ }^{4}$. The benefits in terms of patient compliance, rapid onset of action, increased bioavailability and good stability make these tablets popular as a dosage form of choice in the current market. Some drugs are absorbed from the mouth, pharynx and oesophagus when the saliva passes down into the stomach, in such cases bioavailability of drug is significantly greater than those observed from conventional tablet dosage form ${ }^{5,6}$.
ODTs with good taste and flavor increase the acceptability of bitter drugs by various groups of population. Various techniques available for formulating ODTs include freeze drying, sublimation, spray drying, tablet moulding, and melt granulation ${ }^{7}$ etc. Despite the different mechanisms involved in these techniques, the aim is to provide the tablet that quickly disintegrate or dissolve upon contact with saliva and also to provide a good mouth feel.

\section{MATERIALS AND METHOD:}

\section{Materials:}

Donepezil Hydrochloride was obtained as gift sample from RA Chem Pharma Ltd, Hyderabad. Karaya gum, agar and glycine obtained from Yarrow Chem. Products and Kyron T-314 from Corel Pharma Chem Ltd.

*Corresponding Author:

Prof. Dr. P.K. Lakshmi,

HOD, Department of Pharmaceutics, G.Pulla Reddy College of Pharmacy, Hyderabad. E-mail:drlakshmisuresh@gmail.com Mobile: +91-9000044452. 


\section{Methods:}

Preparation and evaluation of modified karaya gum and modified agar: Modified karaya gum was prepared from tears of karaya gum, were pulverized and then passed through sieve No.100. Ten grams of the powdered gum was taken in a china dish and subjected to heating at $120^{\circ} \mathrm{C}$ for 2 hours in a hot air oven, and for modified agar the powder was mixed with distilled water and stirred, then kept for swelling. It was kept for three days for drying and ground to pass through sieve No.100. Both the modified gums were evaluated for viscosity (Brookefield viscometer LV DV-II+Pro) and swelling index.
Preparation and evaluation of donepezil hydrochloride oro-dispersible tablets:

Formulation of orodispersible tablets of DPH with glycine \& mannitol as excipient:

$5 \mathrm{mg}$ tablets of total weight $50 \mathrm{mg}$ containing $40-60 \%$ of glycine and mannitol were prepared but all were found to show poor flow property.

Formulation of orodispersible tablets of DPH with modified karaya gum and modified agar

Table 1: Formulation of ODT of DPH containing modified gums

\begin{tabular}{|c|c|c|c|c|}
\hline Formulation & Drug(mg) & Modified karaya gum (mg) & Modified agar (mg) & Lactose (mg) \\
\hline DPHMK $_{1}$ & 5 & 2.5 & - & 42 \\
\hline DPHMK $_{2}$ & 5 & 3.75 & - & 40.75 \\
\hline DPHMK3 $^{\text {DPHMA }}$ & 5 & 5 & - & 39.5 \\
\hline DPHMA $_{2}$ & 5 & - & 3.5 & 42 \\
\hline DPHMA $_{3}$ & 5 & - & 5 & 40.75 \\
\hline
\end{tabular}

Note: All the above formulations of tablets $2 \%$ PVPK-30 was added as binder, $0.25 \mathrm{mg}$ of Mg.stearate and talc. Total weight of tablet was $50 \mathrm{mg}$.

Uniformly mixed blend was compressed into tablets containing $5 \mathrm{mg}$ drug using $6 \mathrm{~mm}$ flat face surface punches on a Rimek-1 rotary tablet machine by direct compression method.

\section{Evaluation of oral disintegrable tablets:}

\section{Wetting time:}

Five circular tissue papers of $10-\mathrm{cm}$ diameter were placed in a petri dish with a $10-\mathrm{cm}$ diameter. $10 \mathrm{ml}$ of water at $37^{\circ} \mathrm{C} \pm 0.5^{\circ} \mathrm{C}$ containing eosin, a water-soluble dye, was added to the petri dish. A tablet was carefully placed on the surface of tissue paper. The time required for water to reach the upper surface of the tablets was noted as the wetting time. Six tablets from each formulation batch were tested randomly and the average reading noted.

\section{Water absorption ratio:}

A piece of tissue paper folded twice was placed in a small Petri dish containing $6 \mathrm{ml}$ of water. A tablet was put on the paper and the time required for complete wetting was measured. The wet tablet was weighed.

Water absorption ratio $\mathrm{R}$, was determined using following equation

$$
\mathrm{R}=\mathrm{W}_{\mathrm{a}}-\mathrm{W}_{\mathrm{b}} / \mathrm{W}_{\mathrm{b}} \times 100 \ldots
$$

Where $\mathrm{W}_{\mathrm{a}}=$ weight of tablet after absorption

$$
\mathrm{W}_{\mathrm{b}}=\text { weight of tablet before absorption }
$$

\section{Disintegration time:}

Disintegration time was measured using a modified disintegration method. For this purpose, a Petri dish was filled with $10 \mathrm{ml}$ of water at $37^{\circ} \mathrm{C} \pm 0.5^{\circ} \mathrm{C}$. The tablet was carefully put in the centre of the petridish and the time for the tablet to completely disintegrate into fine particles was noted

Assay:

20 tablets were randomly selected and average weight was calculated. Tablets were powdered in a glass mortar. Powder equivalent to $5 \mathrm{mg}$ was weighed and dissolved in $100 \mathrm{ml}$ of $0.1 \mathrm{~N} \mathrm{HCl} \mathrm{ml} \mathrm{volumetric} \mathrm{flask.}$ This dispersion was filtered and $1.2 \mathrm{ml}$ of the above solutions were taken and diluted to $10 \mathrm{ml}$ with $0.1 \mathrm{~N}$ $\mathrm{HCl}$. The absorbances of this solution were determined at $230 \mathrm{~nm}$ against the blank. The percentage assay was calculated from the standard curve.

\section{In-vitro release:}

In-vitro drug release of oral disintegrable tablets was determined using USP dissolution apparatus II (Paddle type) (Electrolab TDT-08L). The dissolution test was performed using $900 \mathrm{ml} 0.1 \mathrm{~N} \mathrm{HCL}$ at $37^{\circ} \mathrm{C} \pm 0.5^{\circ} \mathrm{C}$. The speed of rotation of paddle was set at $50 \mathrm{rpm} .5 \mathrm{ml}$ samples were withdrawn at time points of $1,3,5,10$, 15, $20 \mathrm{~min}$ and same volume was replaced with fresh media. Absorbance of solution was checked by UV spectrophotometer (ELICO- 164 double beam spectrophotometer) at a wavelength of $230 \mathrm{~nm}$ and drug release was determined from standard curve.

Formulation of orodispersible tablets using modified polysaccharides with glycine/mannitol ${ }^{8}$

Modified karaya gum/Modified agar was mixed with glycine/mannitolin a glass pestle mortar and triturated for $20 \mathrm{~min}$. The ground mixture was passed through sieve No.22 to get the modified polysaccharides with glycine or mannitol. 
Table 2: Formulation of ODT of DPH containing modified gums with glycine

\begin{tabular}{|c|c|c|c|c|c|c|c|c|c|c|c|}
\hline Formulation & Drug (mg) & $\begin{array}{c}\text { Modified } \\
\text { karaya gum } \\
(10 \%)\end{array}$ & Glycine & Mannitol & Lactose (mg) & Formulation & $\begin{array}{c}\text { Drug } \\
(\mathbf{m g})\end{array}$ & $\begin{array}{c}\text { Modified } \\
\text { agar } \\
(\mathbf{1 0 \%}) \\
\end{array}$ & Glycine & Mannitol & Lactose (mg) \\
\hline DPHMKM $_{1}$ & 5 & 5 & $20 \mathrm{mg}$ & - & 19.5 & DPHMAM $_{1}$ & 5 & 5 & $20 \mathrm{mg}$ & - & 19.5 \\
\hline DPHMKM $_{2}$ & 5 & 5 & $25 \mathrm{mg}$ & - & 14.5 & DPHMAM $_{2}$ & 5 & 5 & $25 \mathrm{mg}$ & - & 14.5 \\
\hline DPHMKM $_{3}$ & 5 & 5 & $30 \mathrm{mg}$ & - & 9.5 & DPHMAM $_{3}$ & 5 & 5 & $30 \mathrm{mg}$ & - & 9.5 \\
\hline DPHMKG $_{1}$ & 5 & 5 & - & $20 \mathrm{mg}$ & 19.5 & DPHMAG $_{1}$ & 5 & 5 & - & $20 \mathrm{mg}$ & 19.5 \\
\hline $\mathrm{DPHMKG}_{2}$ & 5 & 5 & - & $25 \mathrm{mg}$ & 14.5 & DPHMAG $_{2}$ & 5 & 5 & - & $25 \mathrm{mg}$ & 14.5 \\
\hline DPHMKG $_{3}$ & 5 & 5 & - & $30 \mathrm{mg}$ & 9.5 & DPHMAG $_{3}$ & 5 & 5 & - & $30 \mathrm{mg}$ & 9.5 \\
\hline
\end{tabular}

Note: All the above formulations of tablets containing different concentrations and it contain $0.25 \mathrm{mg}$ of Mg.stearate and talc. Total weight of tablet is $50 \mathrm{mg}$.

From these preparations the optimized formulations were formulated with spray dried lactose and with various proportions of Kyron K-314 were prepared

Table 3: Formulation of optimized formulations with spray dried lactose

\begin{tabular}{|c|c|c|c|c|c|}
\hline FORMULATION & Drug(mg) & MKG(mg) & MAG(mg) & $\begin{array}{c}\text { Kyron } \\
\text { K-314 }\end{array}$ & $\begin{array}{c}\text { Spray dried } \\
\text { Lactose(mg) }\end{array}$ \\
\hline DPHMKG $_{\mathbf{2}} \mathbf{S}$ & 5 & 30 & - & - & 14.5 \\
\hline DPHMKG $_{\mathbf{3}} \mathbf{S}$ & 5 & 35 & - & - & 9.5 \\
\hline DPHMAG $_{\mathbf{2}} \mathbf{S}$ & 5 & - & 30 & - & 14.5 \\
\hline DPHMAG $_{\mathbf{3}} \mathbf{S}$ & 5 & - & 35 & - & 9.5 \\
\hline DPHK $_{\mathbf{1}} \mathbf{S}$ & 5 & - & - & 0.4 & 44.01 \\
\hline DPHK $_{\mathbf{2}} \mathbf{S}$ & 5 & - & - & 0.5 & 44 \\
\hline DPHK $_{\mathbf{3}} \mathbf{S}$ & 5 & - & - & 0.6 & 43.9 \\
\hline
\end{tabular}

Note: All the above formulations of tablets containing different concentrations of $0.25 \mathrm{mg}$ of $\mathrm{Mg}$. stearate and talc. Total weight of tablet is $50 \mathrm{mg}$.

Comparative evaluations of optimized modified agar formulations were compared with optimized Kyron-T314 formulations.

\section{Accelerated stability studies:}

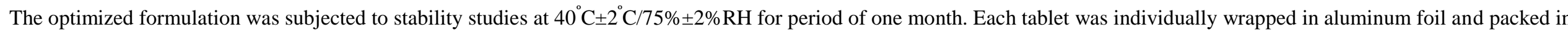

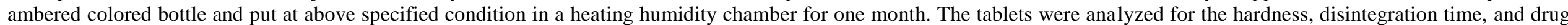
content and in-vitro drug release. 
RESULTS AND DISCUSSION:

Evaluation of Orodispersible tablets of DPH using modified karaya gum and modified agar:

Table 4: Post compression parameters of orodispersible tablets of DPH using modified karaya gum and modified agar

\begin{tabular}{|c|c|c|c|c|c|c|c|c|c|c|}
\hline Formulation & $\begin{array}{c}\text { Weight } \\
\text { variation } \\
(\mathrm{mg})\end{array}$ & $\begin{array}{l}\text { Hardness } \\
(\mathbf{k g} / \mathbf{c m} 2)\end{array}$ & $\begin{array}{c}\text { Thickness } \\
\text { (mm) }\end{array}$ & $\begin{array}{c}\text { Friability } \\
(\%)\end{array}$ & $\begin{array}{l}\text { Disintegration } \\
\text { time (sec) }\end{array}$ & $\begin{array}{l}\text { Wetting time } \\
\text { (sec) }\end{array}$ & $\begin{array}{c}\text { Water } \\
\text { absorption } \\
\text { ratio }\end{array}$ & $\begin{array}{c}\text { Content } \\
\text { uniformity } \\
(\%)\end{array}$ & Assay & $\mathbf{Q}_{20}$ \\
\hline DPHMA1 & $51 \pm 1.05$ & 2.5 & $2.71 \pm 0.02$ & $0.22 \pm 0.18$ & $30 \pm 1.96$ & $35 \pm 1.12$ & $132 \pm 1.42$ & $99.24 \pm 0.58$ & $99.22 \pm 0.51$ & $95.67 \pm 0.50$ \\
\hline DPHMA2 & $50 \pm 0.89$ & 2.5 & $2.69 \pm 0.01$ & $0.25 \pm 0.24$ & $25 \pm 1.21$ & $27 \pm 1.32$ & $135 \pm 1.46$ & $99.85 \pm 0.86$ & $98.82 \pm 0.65$ & $96.90 \pm 1.47$ \\
\hline DPHMA3 & $49 \pm 0.98$ & 3 & $2.72 \pm 0.04$ & $0.22 \pm 0.15$ & $20 \pm 1.90$ & $25 \pm 1.76$ & $137 \pm 1.38$ & $99.62 \pm 0.69$ & $99.64 \pm 0.54$ & $94.38 \pm 1.28$ \\
\hline DPHMK1 & $50 \pm 0.98$ & 2 & $2.71 \pm 0.02$ & $0.28 \pm 0.21$ & $50 \pm 1.24$ & $55 \pm 1.57$ & $139 \pm 1.26$ & $99.45 \pm 0.68$ & $99.02 \pm 0.59$ & $94.27 \pm 1.26$ \\
\hline DPHMK2 & $50 \pm 1.86$ & 2.5 & $2.69 \pm 0.04$ & $0.27 \pm 0.16$ & $35 \pm 1.52$ & $40 \pm 1.43$ & $113 \pm 1.81$ & $99.62 \pm 0.99$ & $99.26 \pm 0.78$ & $95.53 \pm 1.64$ \\
\hline DPHMK3 & $52 \pm 0.86$ & 3 & $2.72 \pm 0.02$ & $0.27 \pm 0.16$ & $25 \pm 1.23$ & $30 \pm 1.65$ & $123 \pm 1.43$ & $99.65 \pm 0.79$ & $99.36 \pm 0.89$ & $96.78 \pm 1.71$ \\
\hline
\end{tabular}

From the above results modified agar preparation (DPHMA3) was found to show better DT compared with modified karaya gum preparations but the \%release was less.

Evaluation of orodispersible tablets of DPH using modified karaya gum with glycine and mannitol

Table 5: Post compression parameters of orodispersible tablets of DPH using modified karaya gum with glycine and mannitol

\begin{tabular}{|c|c|c|c|c|c|c|c|c|c|c|}
\hline Formulation & $\begin{array}{c}\text { Weight } \\
\text { variation } \\
(\mathrm{mg})\end{array}$ & $\begin{array}{l}\text { Hardness } \\
\left(\mathrm{kg} / \mathrm{cm}^{2}\right)\end{array}$ & $\begin{array}{l}\text { Thickness } \\
\text { (mm) }\end{array}$ & $\begin{array}{c}\text { Friability } \\
(\%)\end{array}$ & $\begin{array}{l}\text { Disintegration time } \\
\text { (sec) }\end{array}$ & $\begin{array}{l}\text { Wetting } \\
\text { time (sec) }\end{array}$ & $\begin{array}{c}\text { Water } \\
\text { absorption } \\
\text { ratio }\end{array}$ & $\begin{array}{c}\text { Content } \\
\text { uniformity } \\
(\%)\end{array}$ & Assay & $\mathbf{Q}_{20}$ \\
\hline DPHMKM $_{1}$ & $50 \pm 1.19$ & 2 & $2.77 \pm 0.12$ & $0.27 \pm 0.12$ & $105 \pm 1.21$ & $120 \pm 1.29$ & $110 \pm 1.23$ & $100.13 \pm 0.3$ & $99.87 \pm 0.69$ & $95.67 \pm 0.50$ \\
\hline DPHMKM $_{2}$ & $52 \pm 1.12$ & 2.5 & $2.59 \pm .04$ & $0.23 \pm 0.18$ & $90 \pm 1.96$ & $105 \pm 1.57$ & $118 \pm 1.29$ & $99.98 \pm 0.69$ & $99.82 \pm 0.58$ & $95.04 \pm 1.47$ \\
\hline DPHMKM $_{3}$ & $50 \pm 0.99$ & 2 & $2.45 \pm 0.01$ & $0.21 \pm 0.12$ & $40 \pm 1.23$ & $44 \pm 1.43$ & $121 \pm 1.30$ & $99.80 \pm 1.23$ & $99.74 \pm 0.46$ & $96.38 \pm 1.28$ \\
\hline DPHMKG $_{1}$ & $51 \pm 1.05$ & 2.5 & $2.71 \pm 0.02$ & $0.22 \pm 0.18$ & $35 \pm 1.24$ & $40 \pm 1.57$ & $132 \pm 1.42$ & $99.24 \pm 0.58$ & $99.74 \pm 0.46$ & $96.3 \pm 1.26$ \\
\hline DPHMKG $_{2}$ & $50 \pm 0.89$ & 3 & $2.69 \pm 0.01$ & $0.25 \pm 0.24$ & $28 \pm 1.52$ & $32 \pm 1.76$ & $135 \pm 1.46$ & $99.85 \pm 0.86$ & $98.69 \pm 0.97$ & $94.83 \pm 1.64$ \\
\hline DPHMKG $_{3}$ & $49 \pm 0.98$ & 3 & $2.72 \pm 0.04$ & $0.22 \pm 0.15$ & $22 \pm 1.90$ & $28 \pm 1.32$ & $137 \pm 1.38$ & $99.62 \pm 0.69$ & $99.45 \pm 0.88$ & $96.28 \pm 1.71$ \\
\hline
\end{tabular}

From the above formulations modified karaya gum with glycine(DPHMKG3) has shown good DT and \%release pattern.

Evaluation of Orodispersible tablets of DPH using modified agar with glycine and mannitol

Table 6: Post compression parameters of orodispersible tablets of DPH using modified agar with glycine and mannitol

\begin{tabular}{|c|c|c|c|c|c|c|c|c|c|c|}
\hline Formulation & $\begin{array}{c}\text { Weight } \\
\text { variation }\end{array}$ & $\begin{array}{c}\text { Hardness } \\
\left(\mathbf{k g} / \mathrm{cm}^{2}\right)\end{array}$ & Thickness & $\begin{array}{c}\text { Friability } \\
(\%)\end{array}$ & $\begin{array}{l}\text { Disintegration time } \\
\text { (sec) }\end{array}$ & $\begin{array}{l}\text { Wetting } \\
\text { time (sec) }\end{array}$ & $\begin{array}{c}\text { Water } \\
\text { absorption } \\
\text { ratio }\end{array}$ & $\begin{array}{c}\text { Content } \\
\text { uniformity } \\
(\%)\end{array}$ & Assay & $\mathbf{Q}_{20}$ \\
\hline DPHMAG $_{1}$ & $50 \pm 0.98$ & 2.5 & $2.71 \pm 0.02$ & $0.28 \pm 0.21$ & $25 \pm 1.23$ & $30 \pm 1.12$ & $139 \pm 1.26$ & $99.45 \pm 0.68$ & $99.48 \pm 0.56$ & $95.67 \pm 0.50$ \\
\hline DPHMAG $_{2}$ & $50 \pm 1.86$ & 2.5 & $2.69 \pm 0.04$ & $0.27 \pm 0.16$ & $17 \pm 1.24$ & $25 \pm 1.32$ & $113 \pm 1.81$ & $99.62 \pm 0.99$ & $99.85 \pm 0.88$ & $95.04 \pm 1.47$ \\
\hline DPHMAG $_{3}$ & $50 \pm 0.86$ & 3 & $2.72 \pm 0.02$ & $0.27 \pm 0.16$ & $15 \pm 1.52$ & $23 \pm 1.76$ & $123 \pm 1.43$ & $99.65 \pm 0.79$ & $99.58 \pm 0.88$ & $96.38 \pm 1.28$ \\
\hline DPHMAM $_{1}$ & $50 \pm 0.98$ & 2 & $2.69 \pm 0.01$ & $0.28 \pm 0.15$ & $25 \pm 1.96$ & $35 \pm 1.57$ & $113 \pm 1.30$ & $99 \pm 0.68$ & $99.85 \pm 0.98$ & $96.3 \pm 1.26$ \\
\hline DPHMAM $_{2}$ & $49 \pm 1.86$ & 2.5 & $2.71 \pm 0.02$ & $0.22 \pm 0.21$ & $20 \pm 1.90$ & $30 \pm 1.43$ & $118 \pm 1.29$ & $99 \pm 0.99$ & $98.89 \pm 0.68$ & $94.83 \pm 1.64$ \\
\hline DPHMAM $_{3}$ & $51 \pm 0.89$ & 3 & $2.72 \pm 0.04$ & $0.25 \pm 0.16$ & $19 \pm 1.52$ & $27 \pm 1.65$ & $121 \pm 1.23$ & $99 \pm 0.79$ & $98.95 \pm 0.98$ & $96.28 \pm 1.71$ \\
\hline
\end{tabular}

From the above, formulations of modified agar with glycine has shown good DT and \% release pattern.

(C) 2011-15, JDDT. All Rights Reserved

ISSN: 2250-1177

CODEN (USA): JDDTAO 


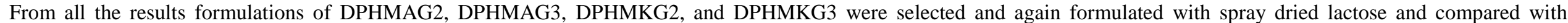
formulations of Kyron-314.

Table 7: Evaluation of optimized formulations and comparison with formulations of Kyron-314

\begin{tabular}{|c|c|c|c|c|c|c|c|c|c|c|}
\hline Formulation & $\begin{array}{c}\text { Weight } \\
\text { variation(mg) }\end{array}$ & $\begin{array}{c}\text { Hardness } \\
\left(\mathbf{k g} / \mathrm{cm}^{2}\right)\end{array}$ & $\begin{array}{l}\text { Thicknes } \\
\text { (mm) }\end{array}$ & $\begin{array}{c}\text { Friability } \\
(\%)\end{array}$ & $\begin{array}{l}\text { Disintegration } \\
\text { time (sec) }\end{array}$ & $\begin{array}{l}\text { Wetting } \\
\text { time (sec) }\end{array}$ & $\begin{array}{c}\text { Water } \\
\text { absorption } \\
\text { ratio }\end{array}$ & $\begin{array}{c}\text { Content } \\
\text { uniformity }(\%)\end{array}$ & Assay & $\mathbf{Q}_{20}$ \\
\hline DPHMKG $_{2} \mathrm{~S}$ & $51 \pm 1.05$ & 1.5 & $2.71 \pm 0.02$ & $0.22 \pm 0.18$ & $25 \pm 1.52$ & $30 \pm 1.43$ & $132 \pm 1.42$ & $99.24 \pm 0.58$ & $99.64 \pm 0.86$ & $97.67 \pm 0.50$ \\
\hline $\mathrm{DPHMKG}_{3} \mathrm{~S}$ & $49 \pm 0.98$ & 2.5 & $2.72 \pm 0.04$ & $0.22 \pm 0.15$ & $20 \pm 1.98$ & $30 \pm 1.57$ & $137 \pm 1.38$ & $99.62 \pm 0.69$ & $98.75 \pm 0.88$ & $97.38 \pm 1.28$ \\
\hline DPHMAG $_{2} \mathrm{~S}$ & $50 \pm 1.86$ & 3 & $2.69 \pm 0.04$ & $0.27 \pm 0.16$ & $15 \pm 1.24$ & $25 \pm 1.32$ & $113 \pm 1.81$ & $99.62 \pm 0.99$ & $99.98 \pm 0.79$ & $98.97 \pm 1.64$ \\
\hline DPHMAG 3 & $50 \pm 0.86$ & 2.5 & $2.72 \pm 0.02$ & $0.27 \pm 0.16$ & $10 \pm 1.52$ & $15 \pm 1.76$ & $123 \pm 1.43$ & $99.65 \pm 0.79$ & $99.94 \pm 0.98$ & $99.79 \pm 1.71$ \\
\hline DPHK $_{1} \mathbf{S}$ & $50 \pm 1.19$ & 2.5 & $2.77 \pm 0.12$ & $0.27 \pm 0.12$ & $50 \pm 1.21$ & $62 \pm 1.21$ & $110 \pm 1.23$ & $101.13 \pm 0.73$ & $99.99 \pm 0.86$ & $94.57 \pm 0.50$ \\
\hline $\mathrm{DPHK}_{2} \mathrm{~S}$ & $52 \pm 1.12$ & 3 & $2.59 \pm .04$ & $0.23 \pm 0.18$ & $30 \pm 1.96$ & $56 \pm 1.92$ & $118 \pm 1.29$ & $99.98 \pm 0.69$ & $99.88 \pm 0.78$ & $95.23 \pm 1.47$ \\
\hline DPHK $_{3} \mathrm{~S}$ & $52 \pm 0.99$ & 3 & $2.45 \pm 0.01$ & $0.21 \pm 0.12$ & $25 \pm 1.23$ & $44 \pm 1.08$ & $121 \pm 1.30$ & $99.80 \pm 1.23$ & $99.98 \pm 0.87$ & $96.57 \pm 1.28$ \\
\hline
\end{tabular}

The comparative study of optimized formulations of modified agar with glycine and with Kyron T-314 showed better disintegration time of 10 and 15 seconds in comparison to Kyron which produced 25 seconds. The wetting time and water absorption ratio of optimized formulations were also better than synthetic superdisintegrant. All the ODT parameters were found to be better than synthetic superdisintegrant.

\section{DISCUSSION}

An attempt has been made to prepare orodispersible tablets of donepezil hydrochloride using modified karaya gum and modified agar with glycine and mannitol. The prepared formulations were compared with Kyron T-314 and spray dried lactose as diluent for improvement in DT and other ODT parameters. The oral dispersible tablets formulated using modified agar with glycine (DPHMAG $\mathrm{DPHMAG}_{3}$ ) showed better disintegration time compared to modified karaya gum

\section{REFERENCES}

1. Chang R, Guo X, Burnside BA, Couch R. A review of fast dissolving tablets. Pharm tech. 2000;24(6):52-58

2. Biy X, Sunada H, Yonezawa Y, Danjo K. Evaluation of rapidly disintegrating tablets prepared by direct compression method.Drugdev.ind.pharm. 1999;25(5):571-581

3. Gohel M, Patel M, Amin A, Agarwal R, Dave R, Bariya N. Formulation design and optimization of mouth dissolve tablets of Nimesulide using vacuum drying technique. AAPS pharm.sci.tech. 2004;5(3):1-6

4. Bhupendra G Prajapati, Nayan Ratnakar. A review on recent patents on fast dissolving drug delivery system. Pharm tech. 2009;1(3):790-798 formulations. Different concentrations of mannitol and glycine were used in the formulation to study the improvement in the DT. The glycine formulations with modified agar gave better ODT parameters than modified karaya gum with mannitol and glycine formulations. The optimized formulations of modified agar with glycine $\left(\mathrm{DPHMAG}_{2}, \mathrm{DPHMAG}_{3}\right.$ in different concentrations were prepared with spray dried lactose as diluent and compared with formulations of Kyron T-314 (DPHK $3 \mathrm{~S}_{\text {) }}$ as superdisintegrant with spray dried lactose as diluent. These formulations (DPHMAG $\mathrm{DPHMAG}_{3}$ gave better ODT profiles compared to Kyron formulations $\left(\mathrm{DPHK}_{3} \mathrm{~S}\right)$ and results of lactose and spray dried lactose as diluents in these formulations did not show any significant difference in ODT evaluation parameters denoting that lactose can be used as diluent for direct compression of this optimized formulation. To conclude, modified polysaccharides with glycine can be used as superdisintegrant, which may be a cost effective alternative in comparison to synthetic superdisintegrant like Kyron T-314.
5. Anupama kalia, Shelly Khurana, Neena bedi. Formulation and evaluation of mouth dissolving tablets of Oxcarbazepine. International journal of pharmacy and pharmaceutical sciences. 2009;1(1):12-23

6. Habib W, Khankari R, Hontz J. Fast-dissolving drug delivery systems: Critical review in therapeutics. Crit rev ther drug carrier syst. 2000;17(1):61-72

7. Biradar SS, Bhagavati ST, Kuppasad IJ. Fast dissolving drug delivery systems: A brief overview The Int. J. Pharmacol. 2006;4(2):1531-2976

8. Vijay Sharma, Anil K, Philip, and Kamla Pathak Modified Polysaccharides as Fast Disintegrating Excipients for Orodispersible Tablets of Roxithromycin, AAPS.2008; 9(1):87-94
〔C 2011-15, JDDT. All Rights Reserved

ISSN: 2250-1177

\section{CODEN (USA): JDDTAO}

